International Journal of Social Science And Human Research

ISSN(print): 2644-0679, ISSN(online): 2644-0695

Volume 04 Issue 05 May 2021

DOI: 10.47191/ijsshr/v4-i5-32, Impact factor-5.586

Page No : 1140-1146

\title{
The Application of Castration to Child Sex Offenders as Legal Protection for Children as Sexual Crimes Victims
}

\author{
Rizka Junisa Dayani ${ }^{1}$, Nyoman Serikat Putra Jaya ${ }^{2}$ \\ ${ }^{12}$ Magister Ilmu Hukum, Fakultas Hukum, Universitas Diponegoro
}

\begin{abstract}
Many cases of sexual crimes against children are happening in society nowadays. Such as cases of sexual violence against children who are victims of pedophilia, cases of rape, cases of rape, and murder. This makes Indonesia an emergency for sexual crimes against children. The research method used was normative juridical. The research specification used was to describe the existing problem (descriptive-analytical), while the data collection method used was library research and documents to be analyzed descriptively-analytically, namely literature and document studies. Indonesia has become a sexual emergency with various cases of sexual crimes against children. To tackle cases of sexual crimes against children, the government made a new regulation with the addition of an additional punishment in the form of castration. The additional punishment of castration against perpetrators of sexual crimes against children is regulated in Law Number 17 of 2016 concerning Stipulation of Government Regulations in Lieu of Law Number 1 of 2016 concerning Child Protection (Perppu on Castration) Second Amendment to Law Number 23 of 2002 concerning Protection Child.
\end{abstract}

KEYWORDS: Sexual Violence, Castration

\section{PRELIMINARY}

\section{A. Introduction}

Nowadays, many cases are still happening in society, namely cases of sexual crimes against children. Cases of sexual crimes against children are varied and very complex, and the mode is even more sophisticated. As cases of sexual assault on children who are victims of pedophilia, rape, rape and murder cases that happen to a junior high school student in the village of Padang Ulak Slam, District Rejong Lebong, Bengkulu Province who was raped and killed by 14 youth after school. Data from the Child Protection Agency shows that up to now there are 21,689,797 cases of children's rights violation and 58\% of them are sexual crimes. Meanwhile, data from the Indonesian Child Protection Commission (Komisi Perlindungan Anak - KPAI) states that there were 22 million children who experienced violence during 2010-2014, and 42\% of them were cases of sexual crimes. ${ }^{1}$

Apart from sexual crimes such as rape, child marriage at an early age can also be a factor in the occurrence of sexual crimes and violence. Children are forced to have sexual relations, forced to become prematurely so that children lose time to play and learn. One of the main causes of the increasing number of cases of sexual crimes is the easier access to pornography in cyberspace, with thousands of sites that are deliberately and served to anyone, anywhere. Therefore there must be a willingness and strict control over these sites.

In essence, children cannot protect themselves from various kinds of sexual crimes that can cause mental, physical, and social harm in various fields of life and livelihood. ${ }^{2}$ In particular, legal protection for children concerning the phenomenon of sexual crimes is protection that is carried out before and after a child becomes a victim of a sexual crime. ${ }^{3}$

The children position as the younger generation who will carry on the noble ideals of the nation, candidates for future leaders of the nation, and as a source of hope for previous generations, need to have the widest possible opportunity to grow and develop normally both spiritually, physically and socially. Child protection is an effort and activity of all levels of society who are fully aware of the importance of children for the country and the nation in the future. ${ }^{4}$

With the increasing prevalence of sexual crimes against children, one option that can be considered optimal for tackling sexual crimes against children is to provide a deterrent effect on the perpetrators. There have been calls from various parties for

\footnotetext{
${ }^{1}$ http//www.komnasham.go.id/kabar-latuharhary/kompas-ham-perppu-tentang-penghukuman-kebiri-untuk-tidak-diterbitkan (diakses pada tanggal 24 Oktober 2018 pukul 14.12 WIB)

2 Ibid, hlm 2

${ }^{3}$ Andika Wijaya dan Wida Peace Ananta, Darurat Kejahatan Seksual, Jakarta: Sinar Grafika, 2016, hlm 89

${ }^{4}$ Maidin Gultom, Perlindungan Hukum Terhadap Anak, Bandung:Refika Aditama, 2006, hlm 33
} 


\section{The Application of Castration to Child Sex Offenders as Legal Protection for Children as Sexual Crimes Victims}

the President of the Republic of Indonesia to immediately ratify the Draft Government Regulation in Lieu of Law regarding the Second Amendment to Law of the Republic of Indonesia Number 23 of 2002 concerning Child Protection, which regulates additional penalties in the form of chemical castration against perpetrators of sexual crimes. In the Perppu, there are two types of punishment, namely basic punishment and additional punishment in the form of castration so that it can provide a deterrent effect on the perpetrator.

Based on the background described above, the authors were interested in conducting a study entitled "The Application of Castration to Child Sex Offenders as Legal Protection for Children as Sexual Crimes Victims".

\section{B. Formulaion of the Problem}

Based on the discussion of the background above, it can be formulated to fundamental issues that will be examined as follows:

1. What are the implications of positivism for legal science?

2. What are the implications of positivism for law enforcement?

\section{Research Purposes} The purposes of this study were as follows:

1. To know the procedure for implementing the castration penalty and to find out the rules used in the implementation of the castration penalty against perpetrators of sexual crimes;

2. This is to determine the optimization of the implementation of castration punishment as legal protection for children as victims of sexual crimes

\section{METHOD}

The method used in this research was normative juridical. The research approach used in writing this law was normative juridical. Normative research is legal research done by researching library materials or secondary materials such as legislations, researches, works of legal experts, and other legal sources which can be accounted for. In this study, secondary data used was data related to the main problem. The specification in this research was descriptive analysis. Descriptive research is research that is intended to describe situations or events. A way of solving problems that are investigated by describing the state of the object at present based on the facts that appear as they are to be analyzed objectively. Descriptive is describing everything that exists, carried out systematically, chronologically based on scientific principles. While analysis is grouping, combining, comparing, and giving meaning by linking legal theories that develop in society so that it is hoped that the causes of these problems can be found. ${ }^{5}$

The method of collecting data from this research was to use secondary data which includes:

1) Primary Legal Materials, binding materials, and consist of Law Number 35 of 2014 concerning Amendments to Law Number 23 of 2002 concerning Child Protection, Law Number 17 of 2016 concerning Stipulation of Substitute Government Regulations Act No. 1 of 2016 on Child Protection (Perppu on Castration) Second Amendment Act No. 23 of 2002 on Child Protection;

2) Secondary Legal Materials, namely materials that are closely related to primary legal materials and can help analyze and understand primary legal materials, including papers and articles relating to the application of castration as protection of children who are victims of sexual crimes; textbooks that contain the application of the punishment of castration as protection of children who are victims of sexual crimes and so on; law journals; and other reference materials.

3) Tertiary legal materials, namely materials that provide guidance and explanation for primary and secondary legal materials which consists of law dictionaries and websites.

The data analysis method is the process of organizing and sorting data into patterns, categories, and basic units of description so that themes can be found and work hypotheses can be formulated as suggested by the data. Research data obtained from the field in the form of primary data are collected and selected systematically, juridical, and logically supported by secondary data then analyzed quantitatively and qualitatively to achieve clarity on the issues discussed.

\section{RESULTS AND DISCUSSION}

\section{A. The Application of Castration as Punishment to Sexual Offender}

1. Criminal and Criminalization

Criminal comes from the word straf (Dutch), which basically can be said as suffering (sorrow) that is deliberately imposed on someone who has been proven guilty of committing a crime. ${ }^{6}$ The term criminal is often interpreted the same as the term punishment. But those terms have different meanings. ${ }^{7}$

\footnotetext{
${ }^{5}$ Lexy J. Moleong, Metodologi Penelitian Kualitatif, Bandung: Remaja Rodakarya, 2005, hlm 257

${ }^{6}$ Muladi dan Barda Nawawi Arief, Teori-Teori dan Kebijakan Pidana, Bandung: Alumni, 2005, hlm 1

${ }^{7}$ Tongat, Pidana Seumur Hidup dalam Sistem Hukum Pidana di Indonesia, Malang, Cetak. Kedua, UMM Press, hlm 59
} 
Punishment is a general meaning, as a sanction that hurts or is deliberately inflicted on someone. While criminal is a special definition related to criminal law. As a special definition, its existence also has similarities with the general definition, namely as a sanction or sorrow for someone to suffer. ${ }^{8}$

Theoretically, a crime is a reaction or offense and takes the form of a sorrow that is deliberately inflicted by the state or state institution on the offender. Sorrow is only an immediate goal, not a final goal that and should be following the coaching efforts (treatment). ${ }^{9}$ Simons, as quoted by Lamintang, stated that crime or straf is an affliction which by the criminal law has been linked to a violation of a norm, which with a judge's decision has been passed on to someone guilty. ${ }^{10}$

Criminalization can be interpreted as the stage of determining sanctions and also the stage of imposing sanctions in criminal law. The word "criminal" is generally defined as law, while "criminalization" is defined as punishment or penalty. ${ }^{11}$ Criminalization is a process. In this process, the judge's role is very important. They concretize criminal sanctions contained in regulation by imposing penalties on certain people in certain cases.

Ted Honderich said that punishment must contain 3 elements. First, punishment must contain a kind of deprivation or distress which is normally formulated as the target of the act of punishment. This first element is a loss or crime suffered by a subject who is a victim as a result of the conscious action of another subject. The actions of other subjects are considered wrong not only because they cause suffering to others, but also because they violate the legitimate law. ${ }^{12}$ Second, every conviction must come from a legally authorized institution as well. Thus, punishment is not a natural consequence of an action, but rather a result of the decisions of the personal actors of a powerful institution. Therefore, punishment is not an act of revenge from the victim against the offender who causes suffering. Third, the authorities have the authority and the right to impose punishment only on subjects who have been proven to have intentionally violated laws or regulations in force in society. ${ }^{13}$

\section{The Castration Penalty}

Castration according to the Big Indonesian Dictionary (Kamus Besar Bahasa Indonesia - KBBI) is that the testicular glands (in male animals) have been removed or the ovaries (in female animals) have been spayed. ${ }^{14}$ Castration is a surgical procedure and/or chemical use that aims to eliminate testicular function in males or ovarian function in females. In the current context, castration is not only applied to animals but also humans with the application of certain criminal laws. ${ }^{15}$

At this time there are 2 types of methods of castration punishment, namely the surgical method or physical castration and the chemical method or chemical castration. The method of surgery or physical castration is done by cutting the external sex organs of the offender which produces testosterone hormones, namely the testes, which as a result for the perpetrator will lose sexual desire and become permanently sterile. In the dark days of Europe, surgical castration was used as a punishment for offenses more directed at heresy or black magic. Surgical castration in women is achieved by removing eggs or ovaries or is called an oophorectomy. During the operation process or oophorectomy, it has a relatively high level of difficulty. After surgery, it takes women at least 4 to 6 weeks to recover before normal activities. While in men, surgical castration has a relatively simple procedure and can usually return to activities as soon as possible after surgery. Surgical methods or physical castration are considered to be very effective in achieving several goals, one of which is to reduce the sexual desire for perpetrators of sexual crimes to prevent recidivism.

Chemical methods or chemical castration are carried out by injecting hormones or antiandrogen chemicals into the offender's body to suppress the production of testosterone hormones in the body to decrease. The result is the same as the physical method of castration, which removes libido or sexual desire or the ability to get an erection, but this method will only stop the perpetrator's passion for a certain time or temporarily castrate. ${ }^{16}$

Both surgical and chemical methods of castration can harm the perpetrator because hormonal manipulation can have unexpected consequences. After all, this hormone is widely spread throughout the body. ${ }^{17}$

\footnotetext{
${ }^{8}$ Andi Hamzah, Sistem Pidana dan Pemidanaan Indonesia: dari Retribusi ke Reformasi, Jakarta, Cetak Pertama, Pradnya

Paramita, 1985, hlm1

${ }^{9}$ Aruan Sakidjo dan Bambang Poernomo, Hukum Pidana: Dasar Aturan Umum Hukum Pidana Kodifikasi, Jakarta, Ghalia Indonesia, 1990, hlm 69

${ }^{10}$ P.A.F.Lamintang, Hukum Penitensier Indonesia, Bandung, Armico, hlm 34

${ }^{11}$ Leden Marpaung, Asas-Teori-Praktik Hukum Pidana, Jakarta, Sinar Grafika, 2005, hlm 2

12 Ter Honderich sebagaimana dikutip oleh M. Sholehuddin, Punishment: The Supposed Justifications, Jakarta, Rajagrafindo

Persada, 2004, hlm 70

${ }^{13}$ Ibid, hlm 71

${ }^{14}$ Andika Wijaya dan Wida Peace Ananta, Op cit, hlm 174

${ }^{15}$ Loc cit

${ }^{16}$ Ahmad Rifai, Varia Peradilan No. 368 Ikatan Hakim Indonesia, Jakarta, Juli 2016, hlm 8

${ }^{17}$ Samantha Valliant Court, Thesis: Chemical Castration: How a Medical Therapy Became Punishment an the Bioethical Imperative to Return to a Rehabilitative Model for Sex Offenders, Winston Salem North Carolina, 2012, hlm 15
} 


\section{The Application of Castration to Child Sex Offenders as Legal Protection for Children as Sexual Crimes Victims}

The chemical castration method is carried out by not only being injected into the perpetrator once it is finished, unlike a person who is physically castrated. They have to take it continuously because the anti-testosterone effect is only temporary. As with other chemical drugs, the anti-testosterone substance depends on the time limit. In addition to injecting anti-testosterone substances, there is another way to do chemical castration, namely by giving the drug Depo Provera which is commonly used as a female contraceptive (family planning drug), because by giving more female hormones to the male body, testosterone production will decrease and lose its function. The impact of chemical castration on a man goes beyond simply decreased sexual desire. The emergence of sexual arousal is not solely caused by the hormone testosterone, but sexual experiences experienced by a person can increase sexual arousal.

Antitestosterone substances that are given regularly to men whose testosterone levels are normal are assumed to cause a decrease in sexual desire in men. However, the impact is more than that. The reason is, the hormone testosterone plays a role in various body functions, not only sexual functions. The impact that will be generated from the decrease in the hormone testosterone will affect the brain so that the mood is uncomfortable, becomes irritable. Then this will have an impact on the skin so that the skin becomes dry and the muscles then shrink, the bones become porous, causing the person to be weak and helpless.

The Draft Government Regulation in Lieu of a Law regarding the Second Amendment to Law of the Republic of Indonesia Number 23 of 2002 concerning Child Protection (RPPUU for Child Protection) was raised when several groups, especially the Government, stated that Indonesia was in a sexual crime emergency status. Sexual crimes against children are increasing significantly, threatening and endangering the lives of children, destroying their personal life and development, and disturbing the sense of comfort, security, and public order. RPPUU Child Protection was established as part of the measures taken by the Government through a revision or two changes to the Law of the Republic of Indonesia Number 23 of 2002 on Child Protection. Perppu Number 1 of 2016 has been mutually agreed upon by members of the House of Representatives to become a law, in this case, Law Number 17 of 2016 concerning Stipulation of Perppu Number 1 of 2016. Recent developments indicate that the government has completed the discussion of the RPPUU for Child Protection in the form of issuance of Government Regulation in Lieu of Law of the Republic of Indonesia Number 1 of 2016 on May 25, 2016. ${ }^{18}$

Consider the letter a of Perppu Number 1 of 2016 where the rampant cases of sexual crimes have been very threatening and endangering the lives and development of children. In another consideration is said that to do prevention, rehabilitation, and provide a deterrent effect against perpetrators of sexual crimes against children, the need for a criminal additional in form of chemical castration. The additional criminal provisions formulated in the provisions of the Government Regulation in Lieu of Law Number 1 of 2016 adhere to the double-track system provisions, which annul the provisions of criminal sanctions and actions in one statutory law, namely the formulation of criminal sanctions consisting of principal punishment and penalty, and also provisions for sanctions against perpetrators of sexual crimes against children. Government Regulation in Lieu of Law Number 1 of 2016, through a long process, the additional punishment for chemical castration is stated in Article 81, Article 82, and Article $81 \mathrm{~A}$ as additional punishment and it can be an option for law enforcement officials, especially judges, to give sentences with the aim of giving deterrent effect on sexual offenders. The additional punishment for chemical castration is considered by the purpose of imposing criminal sanctions as one of the methods used to achieve the goal of holding a criminal sentence.

The imposition of additional penalties which are referred to in Perppu Number 1 of 2016, additional punishment in the form of chemical castration has conditions in its implementation, namely the additional punishment of castration can be imposed on a defendant who has been sentenced to a minimum of 10 years and a maximum of 20 years, the judge's decision is absolute given to the defendant because the judge's decision becomes The main conditions in providing additional castration punishment, additional castration punishment is given to a defendant who is already an adult or over 18 years of age, additional castration punishment is given if the defendant has done it more than once or the victim has more than one victim and if the defendant causes damage to the victim's genitals or victims suffer from sexually transmitted diseases as well as mental disorders or damage to reproductive organs. Additional punishment for castration is given together with the installation of an electronic detector, which is carried out within a maximum period of 2 (two) years and is carried out after the convict has served the basic sentence. This means that a person who has left the prison and when it comes time for him to undertake social reintegration will initiate an additional punishment in the form of chemical castration which can be carried out within a maximum period of two years. In this process of social reintegration, a person who has served the main crime, namely imprisonment, and started to undergo chemical castration does not have sexual stimulation and is unable to have offspring within a certain period of up to two years. ${ }^{19}$

The system for providing additional punishment in the form of castration is only applied to adult perpetrators of sexual crimes. If the perpetrator of the sexual crime is still a child, the state through Article 82 paragraph 8 Government Regulation in Lieu of Law Number 1 of 2016 states that castration punishment does not apply. Sentencing children as perpetrators of sexual crimes can be carried out through several other articles that exist in the child protection law. This specialization takes into account the age of the children who are still minors.

${ }^{18}$ Andika Wijaya dan Wida Peace Ananta, Op Cit, hlm 136

${ }^{19}$ Loc, cit 


\title{
The Application of Castration to Child Sex Offenders as Legal Protection for Children as Sexual Crimes Victims
}

Additional criminal categories of castration as formulated in the provisions of Article 81 Paragraph 7 of Government Regulation in Lieu of Law Number 17 of 2016 are imposed on perpetrators of sexual crimes against children, namely:

a. Parents, guardians, people who have family ties, caregivers of children, educators, education personnel, officials who handle child protection;

b. Been convicted offenders who have committed the crime of child sexual offenses (recidivism);

c. Perpetrators who cause more than one victim, which results in serious injuries, mental disorders, infectious diseases, impaired or loss of reproductive function and/or the victim dies.

The imposition of additional castration is an option for the judge and not an obligation for the judge. The Perppu stipulates that judges can cast a sentence of castration. ${ }^{20}$ This means that judges have a choice not to impose additional punishment of castration on perpetrators of sexual crimes against children. The judge is given the authority to give additional punishment to the perpetrator by his discretion. The judge cannot impose additional castration punishment on every perpetrator of a sexual crime. The Perppu stipulates that additional castration can only be imposed which results in more than one victim, resulting in serious injuries, mental disorders, infectious diseases, impaired or loss of reproductive function, and/or the victim dies, the perpetrator is sentenced to death, life or imprisonment a minimum of 10 years and a maximum of 20 years. ${ }^{21}$ This means that if the perpetrator is not included in that category, the judge cannot impose an additional sentence of castration. So it can be said that the additional punishment of castration has been regulated in such a way that the additional punishment of castration cannot be imposed on the perpetrator of sexual crimes against children, but it must be proven beforehand whether the perpetrator is included in the category of perpetrators who can be subject to additional castration. Although the imposition of additional criminal convictions on castration is above the jurisdiction of the judge, before issuing a decision, there is nothing wrong with the judge having prior consultation with psychologists and medical doctors, because not all the conditions of the perpetrator's body are suitable for the substance that is injected with castration.

To carry out the castration process, the government through the President as the highest authority can give orders or mandates to health workers through Dokpol (Police Doctor) as contained in the Republic of Indonesia National Police Regulation Number 12 of 2011 Article 1 paragraph 1 which states that police doctor, hereinafter abbreviated as Dokpol, is the application of medical science and technology and its supporting sciences for the sake of police duties. Castration is in the interests of the police's duties in the context of law enforcement on decisions made by courts. Senior nurses from other skilled workers who are not bound by oath can also administer castration injections to become executors in carrying out the punishment of castration. Nurses can carry out castration injections because they have met the criteria in health services as contained in the Nursing Law Number 38 of 2014 Article 1 paragraph 3 general provisions which state a nursing service is a form of professional service that is an integral part of service. health based on nursing knowledge and tips aimed at individuals, families, groups, or communities, both healthy and sick. Medical personnel can carry out castration sentences who have experience in their fields as stated in the Health Law Number 36 of 2009 Article 24 paragraph 1 medical personnel must meet the provisions of the code of ethics, professional standards, rights of health service users, service standards and standard operating procedures.

The provision of additional criminal punishment in the form of castration is the last alternative and the imposition of the additional punishment does not eliminate the main punishment. The imposition of additional penalties in the criminal law system must be imposed together with the main punishment, meaning that the additional punishment cannot stand alone. Additional penalties (bijkomende straf) are intended to carry out criminal measures and patterns of prevention against lawbreakers that are expected to develop effectively to prevent and cause a deterrent effect from various types of crimes in society, to create dynamic social control mechanisms. It is hoped that the additional castration penalty given to perpetrators of sexual crimes against children is expected to be more able to deter the bad intentions of the perpetrators, given its strict nature and cause large losses and the severity of the punishment.

Law an additional penalty is used to solve social problems, especially the problem of the sexual crimes are considered as one form of social ills that threaten the course of social order. The legal policy in the form of granting additional penalties is directed at the objectives of social policies which consist of efforts for the welfare and protection of the social community. ${ }^{22}$ The limitation of the main criminal sanction makes the operation of a legal rule not optimal, therefore it requires supporting facilities in terms of punishment. Castration is an additional punishment made by the authorities as a law enforcement policy for sexual crimes that are applied as a last resort for the perpetrator. By referring to the objectives of punishment in Indonesia, namely the absolute theory (retaliation) and the relative theory (usage).

\section{B. The Effectiveness of the Application of Castration as Legal Protection for Child Victims of Sexual Crime}

Child protection is all efforts to create conditions so that every child can exercise their rights and obligations for the children's natural, physical, mental, and social development and growth. Child protection is a manifestation of justice in a society,

\author{
${ }^{20}$ Pasal 81 Ayat 7 Perppu Nomor 1 Tahun 2016 \\ ${ }^{21}$ Pasal 81 Ayat 5 Perppu Nomor 1 Tahun 2016 \\ ${ }^{22}$ Barda Nawawi Arief, Dikutip dari Ragam Jurnal Perkembangan Humaniora Vol. 14 No. 1 April 2014, hlm 71
}




\section{The Application of Castration to Child Sex Offenders as Legal Protection for Children as Sexual Crimes Victims}

thus child protection is sought in various fields of state and social life. Child protection activities have legal consequences, both with written and unwritten laws. The law is a guarantee for child protection activities. Arif Gosita stated that legal certainty needs to have endeavored for the continuity of child protection activities and to prevent fraud that has undesirable negative consequences in the implementation of child protection. ${ }^{23}$

Article 1 point 2 of Law Number 23 of 2002 stipulates that child protection is all activities to guarantee and protect children and their rights so that they can live, develop and participate optimally under human dignity and protection from violence and discrimination. Child protection can also be defined as any effort aimed at preventing, rehabilitating, and empowering children who have experienced child abuse, exploitation, and neglect.

Child protection law is an individual action that is influenced by certain social elements or certain societies such as interests, social institutions, social values, norms. Child protection law can create legal problems that have legal consequences that must be resolved with guidance and based on the law. Child protection law cannot protect children because the law is only a tool or means used as a basis or guide for people who protect children. It is often misinterpreted that the law can protect people. That thought makes people mistakenly believe in the law and think that the law is always right, it cannot be corrected and updated. Protection of children exists in various fields of law because the interests of children are in various fields of family, social, and national life. ${ }^{24}$

This additional punishment in the form of castration is an excuse as a new legal measure against perpetrators of sexual crimes against children so that it can provide a deterrent effect. However, on the other hand, the law that has existed and applied to ensnare perpetrators of sexual crimes against children is deemed unable to provide justice for victims of sexual crimes. The victims who are mostly children who should receive protection receive treatment that can have a traumatic psychological impact that can be prolonged until the children become adults for the rest of their lives and make them lose their future due to the trauma. It is common for victims after becoming adults to become perpetrators of sexual crimes which are the result of deep psychological trauma, and will even continue to loom in their memories when the perpetrator's actions are committed with violence so that it will create a grudge that is difficult to remove.

In Perppu Number 1 of 2016, the provision of additional punishment in the form of castration only emphasizes the interests of the perpetrator, the Perppu victims have not paid attention to the legal protection needed by the victim. The aspect that needs to be considered in Perppu Number 1 of 2016 to be able to provide legal protection for children who are victims of sexual crimes is the need for recovery, healing, and reintegration of victims in the form of restitution and compensation. Restitution and compensation are far more humane and provide great benefits to victims. Andi Hamzah stated that victims of sexual crimes, who are the ones who suffer the most, do not receive as much protection as provided by law to perpetrators of sexual crimes. Legal protection of children who are victims of sexual crimes as part of community protection can be realized in various forms, such as through the provision of restitution and compensation. ${ }^{25}$

The issuance of Perppu Number 1 of 2016 which contains additional castration which is expected to deter the perpetrator, we will only know its effectiveness after this law is implemented and perhaps in the next few years. To find out the effectiveness of the Perppu, there must be data showing that the Perppu can significantly reduce the number of sexual crimes against children, so far no data is showing that there has been a decrease in the number of sexual crimes against children. When we want to know the extent of the effectiveness of the application of the law, it is necessary to know the substance (content) of legislation, institutions related to the scope of legislation in society, how is the process of the birth of a law that should not be born in a hurry. For temporary interests which have bad quality and are not following the needs of the community, the effectiveness or inaction of the application of the rule of law in general also depends on the optimal and professional actions of the law enforcement apparatus to enforce the enforcement of these legal rules starting from the stage of making them, their socialization, the process of enforcing the law, includes the stages of legal discovery (use of legal reasoning, interpretation, and construction) and its application to a concrete case.

\section{CLOSING}

\section{A. Conclusion}

Based on the results of the research and discussion that has been stated in the previous chapter, the following conclusions can be known:

1. The implementation of castration punishment for perpetrators of sexual crimes against children is regulated in Law Number 17 of 2016 concerning Stipulation of Government Regulations in Lieu of Law Number 1 of 2016 concerning Child Protection (Perppu on Castration) Second Amendment to Law Number 23 of 2002 about Child Protection. Additional castration is given to perpetrators of sexual crimes who are adults or more than 18 years old who have been sentenced to a minimum of 10

\footnotetext{
${ }^{23}$ Arif Gosita, Masalah Perlindungan Anak, Jakarta:Akademi Pressindo, 1989, hlm 19

${ }^{24}$ Maidin Gultom, Perlindungan Hukum Terhadap Anak, Bandung: Refika Aditama, 2006, hlm 44

${ }^{25}$ Dikdik dan M. Arief Mansur, Urgensi Perlindungan Korban Kejahatan Antara Norma dan Realita, Jakarta: Raja Grafindo Persada, 2007, hlm 31
} 
years or a maximum of 20 years. Additional penalties for castration are given to criminals who have been convicted of committing a sexual crime (recidivism), causing more than one victim, which can result in serious injuries, mental disorders, disturbed infectious disease or loss of reproductive function and/or the victim dies. The technique of providing additional punishment for castration is carried out by two methods, namely the surgical method or physical castration and the chemical castration method. Surgical method or neuter physical is done by cutting the external sex organs offender while the method of castration chemistry is done by injecting a substance anti-testosterone to the perpetrators regularly given along with the installation of the detector electronics are implemented in the maximum period of two years and implemented after the convict to undergo principal criminal.

2. The additional castration penalty is deemed unable to effectively protect victims of child sexual crimes because the Perppu Number 1 of 2016 only prioritizes the interests of the perpetrators, the Perppu victims have not paid attention to the legal protection needed by the victims. The aspect that needs to be considered in Perppu Number 1 of 2016 to be able to provide legal protection for children who are victims of sexual crimes is the need for recovery, healing, and reintegration of victims in the form of restitution and compensation. Restitution and compensation are far more humane and provide great benefits to victims. The use of additional castration can be said to be effective in the protection of victims of sexual crimes against children after this law is implemented and possibly in the next few years. To find out the effectiveness of the Perppu, there must be data showing that the Perppu can significantly reduce the number of sexual crimes against children, so far no data is showing that there has been a decrease in the number of sexual crimes against children.

\section{B. Suggestion}

1. Various efforts must be made by the government and law enforcers to be able to enact the Perppu Number 1 of 2016 on Child Protection (Perppu on Castration) so that it can run optimally and effectively, namely the need for socialization to the community, law enforcers have begun to apply additional castration against sexual crimes children and the government needs to form a government regulation on the procedure for implementing castration so that there is no confusion when castration has begun to be implemented by law enforcers.

2. To overcome the weakness and deficiency in Perppu Number 1 of 2016 has, it needs special attention in providing legal protection for child victims of sexual crimes such as giving restitution and compensation. Restitution and compensation are far more humane and provide great benefits to victims.

\section{BIBLIOGRAPHY}

1) Ahmad Rifai, Varia Peradilan No. 368 Ikatan Hakim Indonesia, Jakarta, Juli 2016.

2) Andi Hamzah, Sistem Pidana dan Pemidanaan Indonesia: dari Retribusi ke Reformasi, Jakarta, Cetak Pertama, Pradnya Paramita, 1985.

3) Andika Wijaya dan Wida Peace Ananta, Darurat Kejahatan Seksual, Jakarta: Sinar Grafika, 2016.

4) Arif Gosita, Masalah Perlindungan Anak, Jakarta:Akademi Pressindo, 1989.

5) Aruan Sakidjo dan Bambang Poernomo, Hukum Pidana: Dasar Aturan Umum Hukum Pidana Kodifikasi, Jakarta, Ghalia Indonesia, 1990.

6) Barda Nawawi Arief, Dikutip dari Ragam Jurnal Perkembangan Humaniora Vol. 14 No. 1 April 2014.

7) Dikdik dan M. Arief Mansur, Urgensi Perlindungan Korban Kejahatan Antara Norma dan Realita, Jakarta: Raja Grafindo Persada, 2007.

8) http//www.komnasham.go.id/kabar-latuharhary/kompas-ham-perppu-tentang-penghukuman-kebiri-untuk-tidakditerbitkan (diakses pada tanggal 24 Oktober 2018 pukul 14.12 WIB)

9) Leden Marpaung, Asas-Teori-Praktik Hukum Pidana, Jakarta, Sinar Grafika, 2005.

10) Lexy J. Moleong, Metodologi Penelitian Kualitatif, Bandung: Remaja Rodakarya, 2005.

11) Maidin Gultom, Perlindungan Hukum Terhadap Anak, Bandung: Refika Aditama, 2006.

12) Maidin Gultom, Perlindungan Hukum Terhadap Anak, Bandung:Refika Aditama, 2006.

13) Muladi dan Barda Nawawi Arief, Teori-Teori dan Kebijakan Pidana, Bandung: Alumni, 2005.

14) P.A.F.Lamintang, Hukum Penitensier Indonesia, Bandung, Armico.

15) Samantha Valliant Court, Thesis: Chemical Castration: How a Medical Therapy Became Punishment an the Bioethical Imperative to Return to a Rehabilitative Model for Sex Offenders, Winston Salem North Carolina, 2012.

16) Ter Honderich sebagaimana dikutip oleh M. Sholehuddin, Punishment: The Supposed Justifications, Jakarta, Rajagrafindo Persada, 2004,

17) Tongat, Pidana Seumur Hidup dalam Sistem Hukum Pidana di Indonesia, Malang, Cetak. Kedua, UMM Press. 